\title{
Radionuclide Total Dose
}

National Cancer Institute

\section{Source}

National Cancer Institute. Radionuclide Total Dose. NCI Thesaurus. Code C69291.

The total amount of radioisotope administered during a diagnostic or therapeutic event. 